\section{Geographic Information Systems Show Impact of Field Placement on sh2 Sweet Corn Stand Establishment}

\author{
Amy Barr, ${ }^{1}$ M ark Bennett, ${ }^{2}$ \\ and J ohn Cardina 3
}

Additional WORds. Zea mays, precision farming, GIS

SUMmary. The objective of this study was to ascertain if stand establishment of sh2 sweet corn (Zea mays L.) would benefit from variable planting depths determined by the use of geographic information systems (G IS). Spring and fall research plots were established in a field [ $80 \times 20 \mathrm{~m}(262 \times 66$ ft)] containing C rosby silt loam and Kokomo silty clay loam soil series in Columbus, 0 hio. Three $\$ 2$ sweet corn cultivars (Starship, Skyline, and Confection) were planted at three depths on the two soil types in the fall study, with an additional transition soil added in the spring. E mergence counts as well as soil moisture and temperature were monitored. In the spring, sites were also sampled for nutrient levels and soil compaction. Significant variability was found within the field with respect to soil moisture, temperature, nutrient levels,

Salaries and research support provided by state and federal fundsappropriated to the $\mathrm{O}$ hio StateU niversity Agricultural R esearch and D evelopment C enter. $M$ anuscript H CS 98-32. This paper is a portion of a thesis submitted by A. Barr in partial fulfillment of M S degree requirements at $\mathrm{O}$ hio State U niversity. We acknowledge Jay Johnson for his help with the design and implementation of this project. The cost of publishing this paper was defrayed in part by the payment of page charges. U nder postal regulations, this paper therefore must behereby marked adverti sement solely to indicate this fact.

${ }^{1}$ Former graduate student. Current address: 9144 L ongstone D rive, Lewis Center, OH 43035.

${ }^{2} \mathrm{D}$ epartment of $\mathrm{H}$ orticulture and $\mathrm{C}$ rop Science, $\mathrm{O}$ hio State U niversity, 2021 Coffey Road, Columbus, OH 43210.

${ }^{3} \mathrm{D}$ epartment of $\mathrm{H}$ orticulture and $\mathrm{C}$ rop Science, $\mathrm{O}$ hio State U niversity Agricultural Research and D evelopment C enter, 215 WilliamsH all, Wooster, O H 44691. and compaction. Seedling emergence fluctuated with average soil moisture increasing in blocks with up to $24 \%$ moisture and then leveling off. D aily minimum soil temperatures impacted stand establishment. Although heat units accumulated faster on the C rosby soil, emergence was slower and less complete on these soil series than on Kokomo soil series. Further investigation determined that although temperatures of the $\mathrm{C}$ rosby soil were 3 to $4.5^{\circ} \mathrm{C}\left(5.4\right.$ to $\left.8.1{ }^{\circ} \mathrm{F}\right)$ warmer during the day than the Kokomo soil, temperatures on the C rosby soil averaged $2{ }^{\circ} \mathrm{C}\left(3.6^{\circ} \mathrm{F}\right)$ cooler at night. Analysis of emergence patterns and field variability was performed on ArcView mapping software. Although 'Skyline' planted at $2 \mathrm{~cm}$ (0.8 inches) had the best emergence overall, final stand would have been increased with 'Skyline' planted variably at 2 and $4 \mathrm{~cm}$ (1.6 inches). $M$ apping the field under these different scenarios showed that although area with less than $70 \%$ stand would exist with a $2-\mathrm{cm}$ uniform planting depth, the entire field would have a stand of $70 \%$ or greater with variable planting depth using a high vigor seedlot.

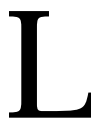

ocation-dependent crop production techniques may improve production efficiency by raising yieldsand lowering amounts of chemicals such as fertilizers and pesticides (Vansichen and De Baerdemaeker, 1993). M onitoring final yields of crops within fields of the same soil type has shown as much as 40\%variability (C hristensen and Krause, 1995). Soil and crop management practices have traditionally been approached on a whole field basis, but recognizing within-field variability would allow for improved precision in crop production (Colvin et al., 1995). M aps of soil productivity and other variables can be produced and used to match agricultural inputs with sitespecific crop needs ( $C$ ahn et al., 1994). M anagement decisionsare usually made by taking soil samples and making a composite to get an averageover afield. Thelarger the cell size for soil sam- pling, the greater the possibility for losing information about field variability (Wollenhaupt et al., 1994). The use of global positioning systems(GPS) and GIS technology allows the creation of maps using a much smaller area.

Precision farming is a system that optimizes crop management on small portions of a field according to its specific characteristics (H uggins and Alderfer, 1995). The purpose of precision farming is to give maximum economic yields while using sustainable practices. $\mathrm{H}$ igh precision includestiming of planting, seed placement in the soil, choosing suitable cultivarsfor field conditions, timing of inputs, and other factors (Wallace, 1994). T he development of GIS has been instrumental to precision farming as it provides a way to store and analyze geographic information. A GIS is a tool for combining data layers into useful information about production and profitability by taking into account static (soils, slope, elevation, etc.) and dynamic (e.g., precipitation, crop cover) data (Griffith, 1995).

TheG PS isa space-based triangu-

Fig. 1. Diagram of field layout for spring study. There are six replications of each treatment per soil type with cultivar remaining the same across row and depth varying by row segment. The plus (+) represents sets of 20 planted seeds; 1-6 refers to blocks and Xs mark locations of data loggers. Dimensions of the field are $80 \times 20 \mathrm{~m}(262 \times 66 \mathrm{ft})$.

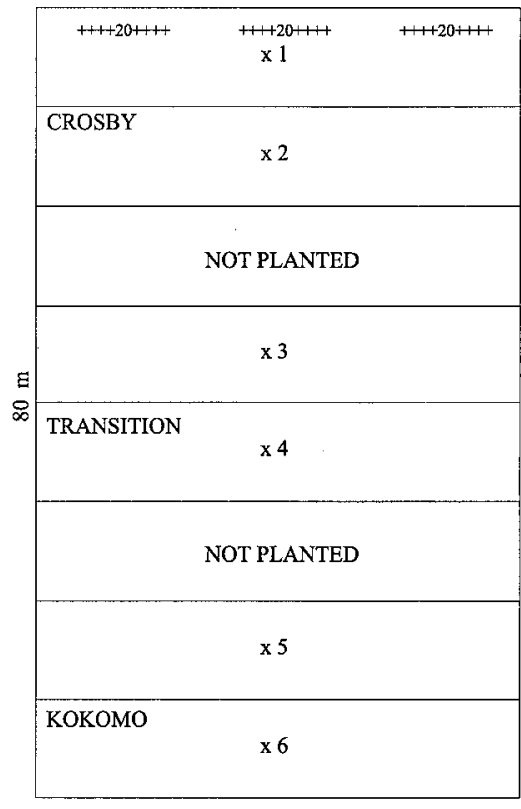

$20 \mathrm{~m}$ 
T able 1. Summary of indices used for field study analysis.

\begin{tabular}{lll}
\hline Index & Season used & Description \\
\hline M aximum emergence & Fall 1996 and Spring 1997 & Peak number of seedlings observed in a plot \\
T otal numbers & Fall 1996 and Spring 1997 & Total number of seedlings observed in a plot throughout study \\
Seedling weight & Fall 1996 and Spring 1997 & A verage weight of a seedling in corresponding plot at three- to four-leaf stage \\
Final count & Spring 1997 & N umber of seedlings observed on day harvested for seedling weight \\
\hline
\end{tabular}

lation system using satellites and computers to measure positions on earth. $D$ eveloped as a defense system by the $U$ nited States D epartment of D efense, it is referred to as the $\mathrm{N}$ avigation Satellite Timing and Ranging Global Positioning System or NAVSTAR GPS (Stafford and Ambler, 1994). The uniqueness of this navigational system is that it avoids the limitations of other land-based systems such as limited geo graphic coverage, lack of continuous 24-h coverage, and the limited accuracy of other related navigational instruments.

Although sh2 sweet corn cultivars are highly desirable especially for the long distance shipping market, poor seed vigor and sporadic seedling disease have limited their acceptance by growers (Wilson et al. 1992). Seeds with the sh2 gene have high sugar endosperm and exhibit a higher risk of preemergence failure than traditional sweet corn (su) hybrids. Achieving successful stand establishment of supersweet corn, especially in cold soils, remains a challenge to growers and researchers.

Seeds are particularly vulnerable to stress between planting and germination (C arter and C hesson, 1996). It isimportant to plant in conditions that favor quick emergence (Price and Gaultney, 1993). Some seedling diseases are more likely to develop in cool, overly moist soil (C arter and Chesson, 1996). R apid corn germination and seedling growth arepromoted by favorable soil temperature, which varies with soil depth, color, moisture, and cover (Williset al., 1957). G rowth activity for most crops is practically suspended at soil temperatures below $4.5^{\circ} \mathrm{C}\left(40.1^{\circ} \mathrm{F}\right)$ (Willis et al., 1957). In the midwestern U .S., optimum soil temperatures are not observed until later in the season when the benefit of early market price has been missed. Assuming that sh2 sweet corn seed will be planted before optimal temperatures are reached, placing the seed in thebest possibleenvironment becomes critical.
$H$ aving narrow windowsfor planting and the desire to get sweet corn harvests as early as possible may also mean that soils have not dried adequately before planting in the field. $\mathrm{N}$ ot only does this introduce seeds into a possibly cold and wet environment, but vehicle traffic particularly when used on wet soils is the most common cause of soil compaction (H akansson et al., 1988). Slower seedling growth in compacted plots prolongs the period when plants are most susceptibleto disease, insects, and competition from weeds (Wolfe et al., 1995). Restricted root distribution due to compacted soil may also lead to reduced shoot growth and yield by limiting water and nutrient availability to the plant ( $\mathrm{H}$ akansson et al., 1988). The Crosby soil series used in this study is more likely to crust after heavy rains than the Kokomo. TheKokomo soil seriestypically hashigher clay content and organic matter and is wetter than the Crosby soil. I ncorporating the differences of soils into management practices could increase stand establishment. The primary objective of this study was to define field conditions using GIS for optimum stand establishment of sh2 sweet corn.

\section{Materials and methods}

The study compared nine treatments consisting of three cultivars planted at each of thefollowing depths: $1.3,2.5$, and $5.1 \mathrm{~cm}(0.5,1$, and 2 inches) in Expts. 1 and 2, 4, and $6 \mathrm{~cm}$ $(0.8,1.6$, and 2.4 inches) in Expt. 2. A randomized split block design wasused with the nine treatments planted in six replications in each soil type (a transition between the Kokomo and C rosby soilswasalso planted in Expt. 2). R ows were divided into three segments with 20 seeds planted in each segment. Cultivar remained the same across an entire row with depth varying by segment. Gaps of $3 \mathrm{~m}$ (10 ft) were left between row segments to assure separation of the treatments in sampling (Fig. 1). Conventional tillagewasused to prepare the seed bed.
EXPERIMENT 1, 1996. Seedling counts were taken daily until emergence had occurred in all nine treatments on both soil types at $12 \mathrm{~d}$ after planting (DAP). Counts were then taken once every $3 \mathrm{~d}$ until frost killed the entire stand on 5 N ovember 1996. O n 150 ctober (27 DAP) when most of the seedlings were at the three to four leaf stage, five seedlings were harvested for each of the 108 plots. Seedlings were chosen as the five closest to the plot but in the $3 \mathrm{~m}$ buffer zone so that germination recordscould becontinued until frost. Theseseedlingswere dried at $57^{\circ} \mathrm{C}\left(135^{\circ} \mathrm{F}\right)$ for $48 \mathrm{~h}$ for biomass determination.

Soil moisture and temperature were measured on the day of planting at all 108 sites at the corresponding depth to the treatment at that site. Soil moisture at seed level was taken with about $1.3-\mathrm{cm}$ increments of soil for wet weight and dry weight determinations after drying for $24 \mathrm{~h}$ at $60{ }^{\circ} \mathrm{C}$ $\left(140^{\circ} \mathrm{F}\right)$. Soil moisture was calculated using the equation: (wet weight - dry weight)/ dry weight. Soil temperature was measured with a thermo couple at the tip of a copper stake that could be pushed into the ground at the appropriate depth.

Three indices were created to measure emergence for the fall study (Table 1). M aximum emergence was the peak number of seedlings that emerged in a plot during the study. This was used instead of a final stand count because, this being a fall study, the stands eventually died off due to cold weather. Thetotal numbersindex is a sum of emergence counts for every day of the study. This index takes into account both the quickness and uniformity of emergence, as well as seedling die-off later in the season. The seedling weight index is the average dry weight for the five seedlings harvested from thevarioustreatment plots at $27 \mathrm{DAP}$.

EXPERIMENT 2, 1997. Seedling counts were again taken daily until all nine treatments had initial emergence (18 DAP). Thereafter, sampling was 
every $3 \mathrm{~d}$ until the seedlings were harvested on 5 J une 1998. The same procedure used in the fall study for taking dry weight samples was followed in spring study except that the entire row of seedlings used for emergence counts was harvested.

$D$ ataloggers ( $\mathrm{H}$ obo XT temperature logger; O nset Computer Corp. Pocasset, $M$ ass.) were placed at six sites in the field and set to record temperature every 30 min throughout the study. The six sites were chosen so that each soil type had two sampling sites and each of thesesites would bein the middle of the northern and southern halves of each soil type. The areas containing these six sites will be referred to as blocks throughout this paper (Fig. 1). Three dataloggerswere buried at each site so that each of the 2,4 , and $6 \mathrm{~cm}$ depths had a corresponding logger. Soil moisture at seed level was taken at the same six sites with about $2-\mathrm{cm}$ increments of soil that were weighed for wet weight and then dry weight after oven drying for $24 \mathrm{~h}$ at $60^{\circ} \mathrm{C}$. Soil moisture determinationsweretaken at the time of planting as in the fall study.

On $20 \mathrm{M}$ ay 1997 (14 D AP) the soil was tested for compaction differences using a neutron probe (3400-B series surface moisture-density gauge; Troxler Electronic Laboratories, Research T riangle Park, N .C.). The probe measured wet and dry soil density. Soil moisture was taken at the same time with this probe. Before emergence, all 162 sites were sampled for soil nutrient analysis. Soil was drawn in $15-\mathrm{cm}$ (6-inch) incrementsfrom thesiteswith soil borers and sent to the Agronomic Service $L$ ab (Washington Court $\mathrm{H}$ ouse, O hio) for determinations of phosphorus, calcium, magnesium, and potassium levels. A GPS receiver (TrimblePro- $\mathrm{XL}$; T rimbleN avigation, Sunnyvale, ( alif.) in a backpack was used to record latitude and longitude coordinates from the perimeter of the field and at the 162 sample points. Differential correction was obtained through a Raycal Landstar receiver (Raycal Survey U SA, Inc., H ouston, Texas). These coordinates were later put into the GIS, ArcView (Environmental Systems Research Institute, Redlands, C alif.) for analysis of seedling emergence and soil moisture, temperature and nutrient variability.

In the spring study, indices used to measure seedling emergence were maximum emergence, total numbers, seedling weight and final count ( $T$ able 1). T otal numbersand maximum emergence indices were calculated by the same methods as the fall study. Final count was total number of seedlings counted and harvested for any given treatment at $30 \mathrm{D} \mathrm{AP}$. T hese seedlings were then weighed and averaged by the count for the seedling weight index.

Statistical analysis. Tests for significance were done using Systat 6.0 for Windows (SPSS I nc., C hicago, III.). Analysis of variancewasconducted for the indices relating to the effects of soil type, cultivar, and planting depth and the combinations of those factors. For tests that were significant at $\mathrm{P}<$ 0.05 , pairwise comparisons were done with the Bonferroni adjustment. (LSD method showed same trend.) A nalysis was also conducted to test for statistically significant differencesin soil moisture, temperature, compaction, and nutrients. This analysis checked to see if within field differences occurred, and whether differences were related to soil type or depth. These factors were also checked against emergence data to determine correlation with emergence patterns. H eat units were calculated for each planting depth in the blocks. M aximum and minimum daily temperatures were acquired from data loggers and used in the following equation: (maximum ${ }^{\circ} \mathrm{C}+$ minimum $\left.{ }^{\circ} \mathrm{C}\right) / 2$ to $10^{\circ} \mathrm{C}$. The resulting calculation gave heat units which were totaled over the course of the spring study ( 6 May to 5 June) and were compared with emergence data.

ArCuEW ANALYsis. O nce data were

Fig. 2. Average emergence on (A) C rosby and (B) Kokomo soil during Expt. 1. Star = 'Starship', Sky = 'Skyline', C onf = 'C onfection'; 1.3, 2.5 , and $5.1=$ planting depths in $\mathbf{~ c m}$ $(0.5,1$, and 2 inches).

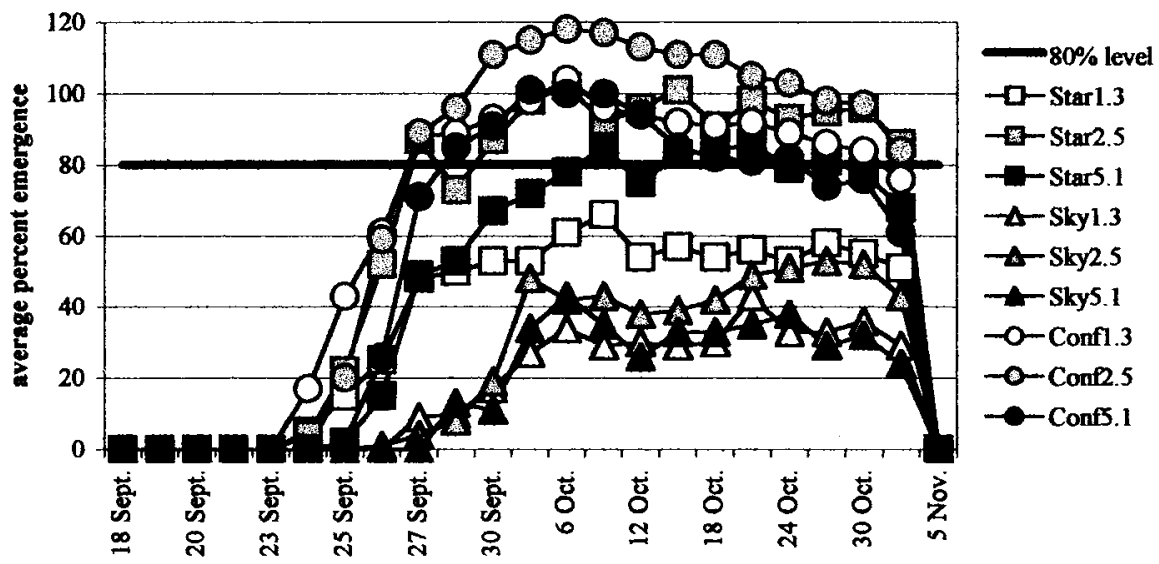

B

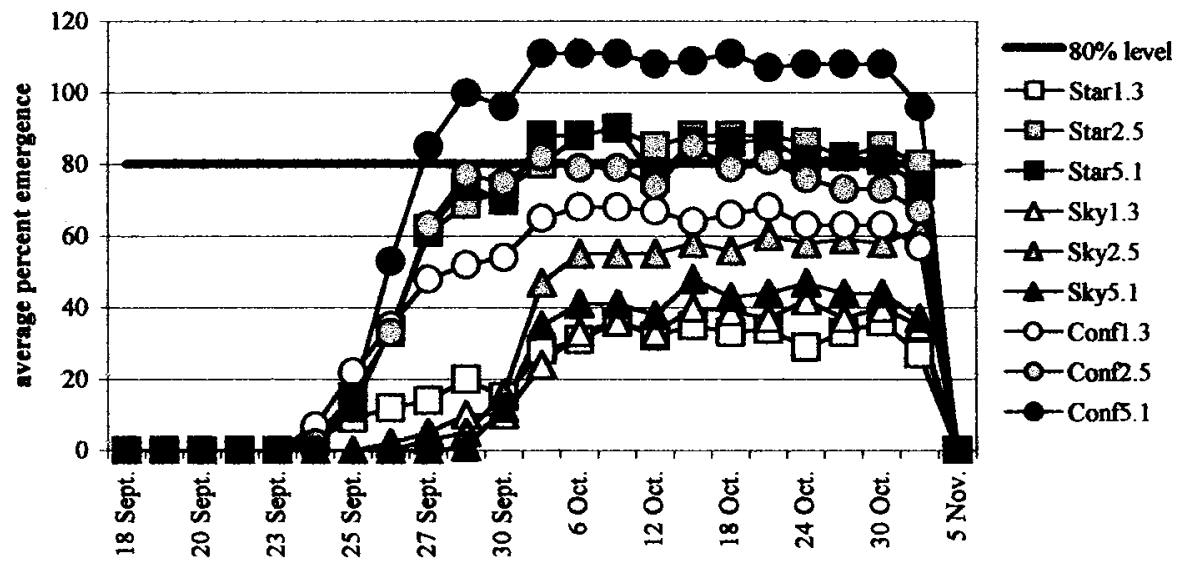

Hor llechnology • A pril-J une 2000 10(2) 
T able 2. Means of indices used in Expt. 1.

\begin{tabular}{|c|c|c|c|c|c|}
\hline $\begin{array}{l}\text { Soil } \\
\text { type }\end{array}$ & C ultivar & $\begin{array}{l}\text { Depth } \\
\text { (cm) }\end{array}$ & $\begin{array}{c}\text { Maximum } \\
\text { emergence } \\
(\%)\end{array}$ & $\begin{array}{c}\text { Total } \\
\text { emergence } \\
\text { (no.) }\end{array}$ & $\begin{array}{c}\text { Avg } \\
\text { seedling } \\
\text { wt (mg) }\end{array}$ \\
\hline \multirow[t]{9}{*}{ Crosby } & Starship & 1.3 & 59 & 136 & 31 \\
\hline & & 2.5 & 89 & 229 & 37 \\
\hline & & 5.1 & 78 & 176 & 32 \\
\hline & Skyline & 1.3 & 35 & 65 & 24 \\
\hline & & 2.5 & 46 & 87 & 29 \\
\hline & & 5.1 & 42 & 64 & 29 \\
\hline & Confection & 1.3 & 88 & 232 & 32 \\
\hline & & 2.5 & 104 & 258 & 27 \\
\hline & & 5.1 & 89 & 202 & 33 \\
\hline \multirow[t]{9}{*}{ Kokomo } & Starship & 1.3 & 31 & 71 & 26 \\
\hline & & 2.5 & 79 & 199 & 52 \\
\hline & & 5.1 & 80 & 196 & 62 \\
\hline & Skyline & 1.3 & 37 & 71 & 30 \\
\hline & & 2.5 & 53 & 108 & 38 \\
\hline & & 5.1 & 41 & 79 & 39 \\
\hline & Confection & 1.3 & 61 & 155 & 38 \\
\hline & & 2.5 & 74 & 186 & 68 \\
\hline & & 5.1 & 98 & 256 & 49 \\
\hline
\end{tabular}

z2.5 cm = 1 inch, $28,350 \mathrm{mg}=1.0 \mathrm{oz}$.

brought into ArcView, the data table was queried to include only 'Skyline' data, as 'Skyline' had produced the highest emergence of the sh2 cultivars. The final count index for 'Skyline' was made into two themes, one with $2 \mathrm{~cm}$ and theother with $4 \mathrm{~cm}$ planting depth. The themes were interpolated using inverse distance weight (IDW) to map emergence over the entire area. IDW was used because it assumes that the points closer to any given area have more in common with that area than points that are further away. To make planting recommendations, calculations were used to find areas where 'Skyline' planted at the 2-cm depth would result in higher final stand counts than 'Skyline' planted at $4 \mathrm{~cm}$. Through the use of the map calculator, percent emergence of 'Skyline' at variable depths was forecasted.

\section{Results and discussion}

EXPERIMENT 1, 1996. Emergence during the fall study generally began around $6 \mathrm{~d}$ after planting (DAP) on both soils, but reached higher levels on the Crosby (Fig. 2A and B). The shallowest planting depth $(1.3 \mathrm{~cm})$ had poor emergence for all cultivars across both soil types. I $n$ all cases, the $1.3 \mathrm{~cm}$ planting depth was slower to emerge than other treatments and never reached levels above $60 \%$ (Fig. $2 \mathrm{~A}$ and B) 'Confection' tended to outperform 'Starship' on the Crosby soil but most treatments of both cultivars suffered at least a $15 \%$ loss of maximum emergencelevels on Kokomo soil. 'Skyline' had the lowest emergence on both soil series, averaging $30 \%$ to $45 \%$ emergence on Crosby and $40 \%$ to $50 \%$ emergence on Kokomo soil (Fig. 2A and $\mathrm{B}$ ).

$M$ aximum emergence ranged from $5 \%$ to $100 \%$, and average seedling weight per plot ranged from 10 to 105 $\mathrm{mg}(0.00035$ to $0.0037 \mathrm{oz})$. Significantly higher maximum emergencewas found on Crosby than on the Kokomo soil series, but the average seedling weight was higher on the Kokomo than the Crosby soil (T able 2). C ultivar rankings from highest to lowest emergence were 'Confection' > 'Starship' > 'Skyline' for all three indices. Cold tests had given the same cultivar ranking in a previous lab study (Barr, 1998). The 2.5- and 5.1-cm planting depths emerged significantly better than the 1.3-cm depth according to all indices. There were no significant effects of soil and cultivar interactions. There was a significant soil and depth interaction as the shallow $1.3-\mathrm{cm}$ depth had higher maximum emergence and total numbers on the C rosby than on Kokomo. The $2.5-\mathrm{cm}$ depth had higher total numbers on C rosby, but average seedling weight at this planting depth was significantly higher on Kokomo (Tables 2 and 3). The deepest planting depth of $5.1 \mathrm{~cm}$ showed significantly higher total numbers and seedling weight on Kokomo soil. Although there was no significancein thecultivar and depth interaction according to the seedling weight index, both maximum emergence and total numbers showed that 'Starship' no longer outperformed 'Skyline' at

Table 3. Analysis of variance for indices used in Expt. 1.

\begin{tabular}{|c|c|c|c|}
\hline Soil treatment (S) & Crosby>Kokomo* & NS & Kokomo>Crosby ${ }^{* *}$ \\
\hline D epth (D) & 2.5 and $5.1>1.3 \mathrm{~cm}^{* *}$ & 2.5 and $5.1>1.3 \mathrm{~cm}^{* *}$ & 2.5 and $5.1>1.3 \mathrm{~cm}^{* *}$ \\
\hline$S \times D$ & $\begin{array}{l}1.3 \mathrm{~cm}: \text { Crosby>Kokomo* } \\
2.5 \text { and } 5.1 \mathrm{~cm}: \text { No difference }\end{array}$ & $\begin{array}{l}5.1 \mathrm{~cm}: \text { Kokomo>C rosby } \\
2.5 \text { and } 1.3 \mathrm{~cm}: \text { Crosby>Kokomo** }\end{array}$ & $\begin{array}{l}2.5 \text { and } 5.1 \mathrm{~cm} \text { : Kokomo>Crosby } \\
1.3 \mathrm{~cm} \text { : No difference }\end{array}$ \\
\hline$C \times D$ & $\begin{array}{l}\text { Starship: } 2.5 \text { and } 5.1>1.3 \mathrm{~cm}^{*} \\
\text { Confection and Skyline: N o difference }\end{array}$ & $\begin{array}{l}\text { Starship: } 2.5 \text { and } 5.1>1.3 \mathrm{~cm}^{* *} \\
\text { Confection and Skyline: N o difference }\end{array}$ & NS \\
\hline
\end{tabular}




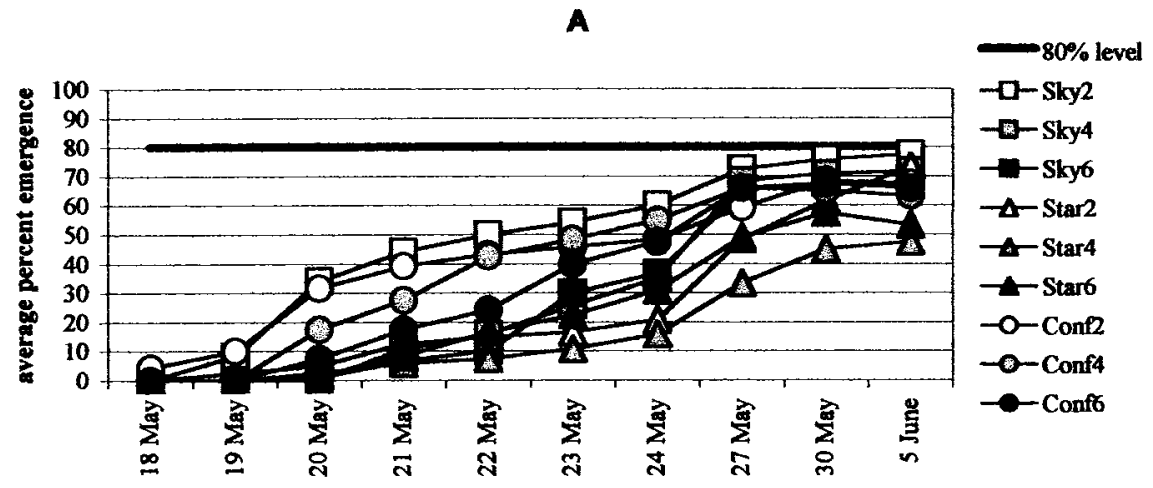

$\mathbf{B}$

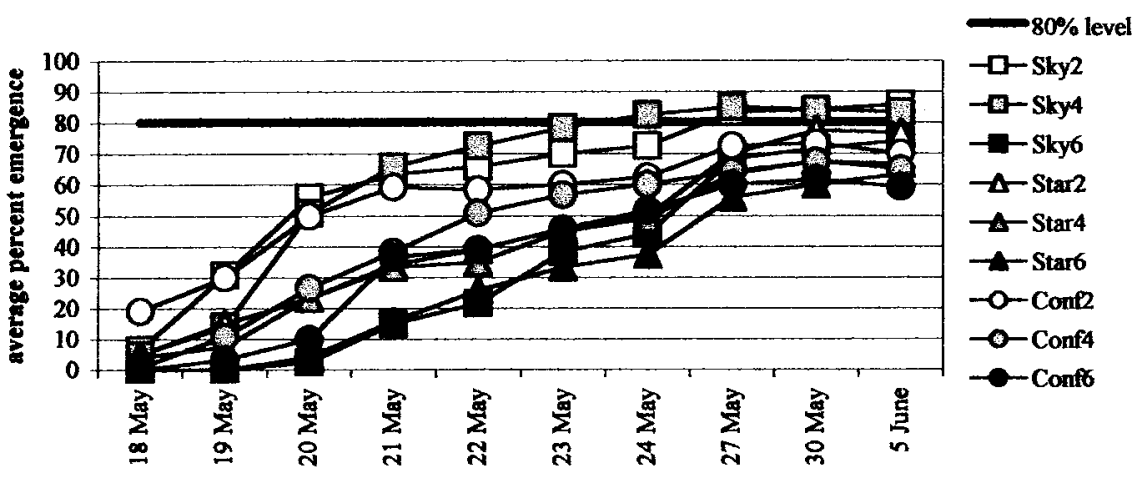

C

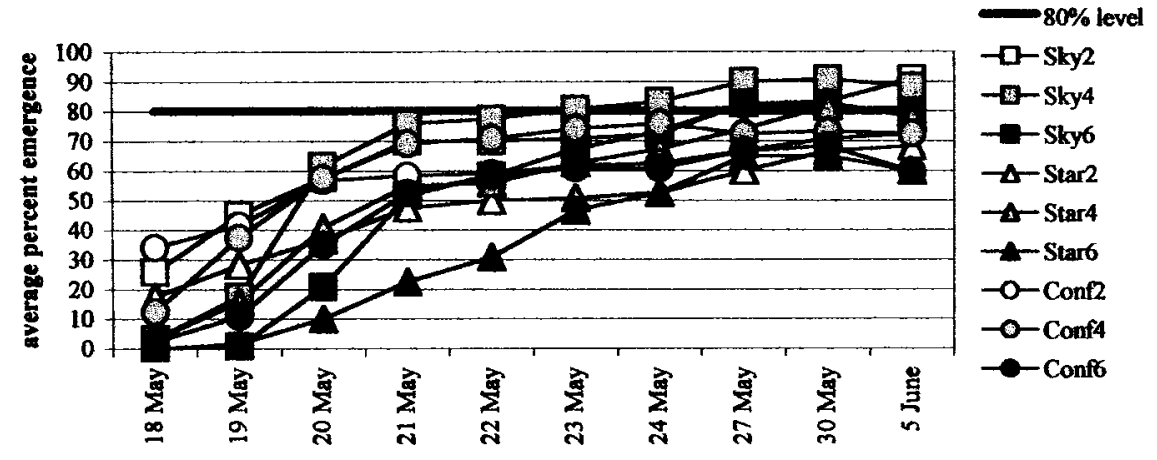

Fig. 3. Average emergence on (A) Crosby, (B) transition, and (C) Kokomo soil during Expt. 2. Sky = 'Skyline', Star = 'Starship', C onf = 'C onfection'. 2, 4, and 6 = planting depths in $\mathrm{cm}(0.8,1.6$, and 2.4 inches).

the shallow 1.3-cm planting depth (Table 3).

Soil moisture and temperature data taken at the time of planting were both significantly affected by depth, with the $1.3 \mathrm{~cm}$ depth being warmer and dryer than the $2.5-\mathrm{cm}$ depth, which were significantly warmer and dryer than the $5.1 \mathrm{~cm}$ depths. Soil temperature was warm for the beginning of the study ranging from 17.5 to $23.1{ }^{\circ} \mathrm{C}$ $\left(63.5\right.$ to $\left.73.6^{\circ} \mathrm{F}\right)$. Soil moisture at seed level ranged from $11 \%$ to $31 \%$. Al- though the average soil moisturelevels wereslightly higher on Kokomo (21\%) than on C rosby (20\%) soil typedid not show any significance with respect to soil temperature. M aximum emergence did not show a significant correlation with soil moisture or temperature at planting (data not shown).

I t isinteresting that Kokomo provided a 50\% increase in average mean seedling mass over the Crosby soil, although maximum emergence averaged $8.5 \%$ higher on the Crosby than the Kokomo soil. This could be partly due to there being a higher organic matter content in the Kokomo soil. The seedlings on the Crosby soil reached maximum emergenceearlyand then began to decline soon after (Fig. 2A). T he decline was not seen as soon (and was less severe) for the Kokomo soil (Fig. 2B). The plots were harvested for seedling weight measurements on $150 \mathrm{ct}$. (27 D AP) when seedlingson theK okomo soil were still at high emergence levels. It is possible that extra cold stress had been placed on the Crosby seedlings accounting for the different seedling mass.

When planted at the shallowest depth, some of the seed was not completely covered by the soil. This may explain why the 1.3-cm depths consistently ranked poorly in all three fall emergence indices. To correct for this the planting depth was shifted from $1.3,2.5$, and $5.1 \mathrm{~cm}$ to 2,4 , and $6 \mathrm{~cm}$ in the spring.

EXPERIMENT 2, 1997. Emergence during the spring study was generally higher on the dark Kokomo soil than on the Crosby. On 5 J une 1997 (30 DAP) when all emerged seedlings had reached the three- to four-leaf stage, they were harvested from sample plots. E mergence ranged from $45 \%$ to $78 \%$ on Crosby (Fig. 3A), $58 \%$ to $85 \%$ on the transition soil (Fig. 3B), and $60 \%$ to $93 \%$ on Kokomo (Fig. 3C). U nlike the fall results, 'Skyline' had the highest emergence on all soil types. E arliest emergence occurred at the 2-cm planting depth on all three soils. Seeds planted at $6 \mathrm{~cm}$ took longer to emerge and had less final stand than other depths on the transition and Kokomo soils (Fig. 3B and C).

The Kokomo and transition soil produced significantly higher emergence levels than the C rosby according to all four indices used in Expt. 2 (Tables 4 and 5). Cultivars were all significantly different from each other using the maximum emergence index with 'Skyline' > 'Confection' > 'Starship'. C old testsagain ranked cultivars similarly as did the accelerated aging test when a saturated $\mathrm{N}$ aC I solution was used instead of water in previous laboratory studies (Barr, 1998). 'Skyline' was also the top performer in the other indices and ranked significantly higher than 'Starship' in all cases (Table 5). The 2-cm planting depth produced higher emergencelevelsthan the $6 \mathrm{~cm}$ depth according to all indices as did the $4-\mathrm{cm}$ depth in the total numbers and seedling weight indices (Tables 4 and 5). As in Expt. 1, there were no significant effects of soil and cultivar interactions. There were no significant interactions among soil, cultivar, or depth factors relating to 
T able 4. Means of indices used in Expt. 2.

\begin{tabular}{|c|c|c|c|c|c|c|}
\hline $\begin{array}{l}\text { Soil } \\
\text { type }\end{array}$ & C ultivar & $\begin{array}{c}\text { Depth } \\
(\mathrm{cm})\end{array}$ & $\begin{array}{c}\text { Maximum } \\
\text { emergence } \\
(\%)\end{array}$ & $\begin{array}{c}\text { Total } \\
\text { no. }\end{array}$ & $\begin{array}{c}\text { Seedling } \\
\text { wt } \\
(\mathrm{mg})\end{array}$ & $\begin{array}{c}\text { Final } \\
\text { count } \\
(\%) \\
\end{array}$ \\
\hline \multirow[t]{9}{*}{ Crosby } & \multirow[t]{3}{*}{ Starship } & 2 & 74 & 51 & 102 & 74 \\
\hline & & 4 & 49 & 34 & 92 & 48 \\
\hline & & 6 & 59 & 48 & 138 & 54 \\
\hline & \multirow[t]{3}{*}{ Skyline } & 2 & 79 & 95 & 252 & 78 \\
\hline & & 4 & 74 & 60 & 184 & 72 \\
\hline & & 6 & 70 & 57 & 173 & 68 \\
\hline & \multirow[t]{3}{*}{ Confection } & 2 & 69 & 84 & 189 & 68 \\
\hline & & 4 & 69 & 77 & 200 & 64 \\
\hline & & 6 & 69 & 67 & 163 & 66 \\
\hline \multirow[t]{9}{*}{ Transition } & \multirow[t]{3}{*}{ Starship } & 2 & 79 & 87 & 154 & 77 \\
\hline & & 4 & 69 & 79 & 193 & 67 \\
\hline & & 6 & 64 & 59 & 149 & 64 \\
\hline & \multirow[t]{3}{*}{ Skyline } & 2 & 86 & 124 & 291 & 86 \\
\hline & & 4 & 87 & 124 & 413 & 84 \\
\hline & & 6 & 76 & 67 & 176 & 74 \\
\hline & \multirow[t]{3}{*}{ Confection } & 2 & 74 & 111 & 364 & 70 \\
\hline & & 4 & 68 & 88 & 211 & 65 \\
\hline & & 6 & 63 & 74 & 227 & 59 \\
\hline \multirow[t]{9}{*}{ Kokomo } & \multirow[t]{3}{*}{ Starship } & 2 & 69 & 96 & 190 & 69 \\
\hline & & 4 & 82 & 107 & 211 & 79 \\
\hline & & 6 & 66 & 71 & 154 & 60 \\
\hline & \multirow[t]{3}{*}{ Skyline } & 2 & 91 & 134 & 351 & 91 \\
\hline & & 4 & 91 & 134 & 381 & 89 \\
\hline & & 6 & 83 & 103 & 307 & 79 \\
\hline & \multirow[t]{3}{*}{ Confection } & 2 & 75 & 117 & 335 & 73 \\
\hline & & 4 & 76 & 123 & 313 & 73 \\
\hline & & 6 & 70 & 95 & 296 & 60 \\
\hline
\end{tabular}

$22.5 \mathrm{~cm}=1$ inch, $28,350 \mathrm{mg}=1.0 \mathrm{oz}$.

themaximum emergenceor final count indices. According to total numbers and seedling weight indices, there was no difference in emergence at varying planting depthswithin the C rosbysoil, but the $6-\mathrm{cm}$ planting depth under performed the shallower planting depths within Kokomo and transition soils. According to the seedling weight index, there was no difference in 'Starship' seedling weight dueto planting depth but the other cultivars had higher seedling weight at the shal- lower planting depths (Table 5).

Soil moisture at planting ranged from $15 \%$ to $27 \%$ Seeding depth was not a significant factor in soil moisture differences, but soil type and location within soil types were. When soil moisture was analyzed by block, a coefficient of determination value $\left(r^{2}\right)$ of 0.80 resulted. Figure 4A shows moisture differences by blocks. Interestingly, the total numbers index when plotted by block (Fig. 4B) has a strikingly similar appearance to Fig. 4A.
Thus planting sh2 sweet corn at a soil moisture level up to $24 \%$ may prove beneficial to stand establishment while no observed benefit would come from wetter conditions.

Soil temperatures were much cooler in the beginning of the study and grew warmer as the season progressed. This added more stress at the time of germination and emergence. Also, the decline in seedlings due to harsh weather towards the end of the study was not seen as in Expt. 1. Average soil temperatures for the first $10 \mathrm{~d}$ were about $12{ }^{\circ} \mathrm{C}\left(53.6^{\circ} \mathrm{F}\right)$ with the shallower planting depthsdropping to 2 to $3^{\circ} \mathrm{C}\left(3.6\right.$ to $5.4^{\circ} \mathrm{F}$ ) at times. The $6 \mathrm{~cm}$ planting depth had alow of about $5{ }^{\circ} \mathrm{C}\left(41^{\circ} \mathrm{F}\right)$ early on but also did not warm up as much as the shallower depths during the day.

$D$ ata loggers provided more accurate readings of the temperaturethan could be done with thermocouples and gave extra information, such as minimum night time temperatures, that were not available with the daily afternoon readings. The lack of correlation of temperatures to emergence patterns in the fall study was explained using logger temperature data. When temperatures were averaged over the time of the study for each of the six sites, the averages were significantly different from each other but not in any apparent way related to germination. In fact, if the two blocks in each soil type were averaged together the three soils seemed to be almost the exact same temperature with no significant differences.

M inimum soil temperature was a moreuseful predictor of seedling emergence showing an almost linear relationship between blocks with thelight Crosby (blocks 1 and 2 ) soil reaching cooler temperatures than the dark Kokomo (blocks 5 and 6; Fig. 4 C).

T able 5. Analysis of variance for indices used in Expt. $2 .^{z}$

\begin{tabular}{|c|c|c|c|c|}
\hline Index & Maximum emergence & Total no. & Seedling wt & Final count \\
\hline Soil treatment $(\mathrm{S})$ & Kokomo and Tran $>$ Crosby $^{* *}$ & Kokomo $>$ Tran $>$ Crosby $^{* *}$ & Kokomo and Tran $>$ Crosby $^{* *}$ & Kokomo and Tran $>$ Crosby $^{* *}$ \\
\hline Cultivar (C) & Skyline $>$ C onfection $>$ Starship ${ }^{* *}$ & Skyline and Confection>Starship ${ }^{* *}$ & Skyline and Confection>Starship ${ }^{* *}$ & Skyline $>$ C onfection and Starship ${ }^{* *}$ \\
\hline D epth (D) & $2>6 \mathrm{~cm}^{* *}$ & 2 and $4>6 \mathrm{~cm}^{* *}$ & 2 and $4>6 \mathrm{~cm}^{* *}$ & $2>6 \mathrm{~cm} * *$ \\
\hline $\mathrm{S} \times \mathrm{C}$ & NS & NS & NS & NS \\
\hline \multirow[t]{2}{*}{$S \times D$} & NS & Kokomo: 2 and $4>6 \mathrm{~cm}^{* *}$ & Kokomo: 2 and $4>6 \mathrm{~cm}^{*}$ & NS \\
\hline & & Crosby: N o difference & Crosby: N o difference & \\
\hline \multirow[t]{2}{*}{$C \times D$} & NS & NS & Skyline and Confection: 2 and $4>6 \mathrm{~cm}^{* *}$ & \\
\hline & & & Starship: N o difference & NS \\
\hline
\end{tabular}

$22.5 \mathrm{~cm}=1$ inch.

${ }_{\mathrm{Ns},}{ }^{*}, * * \mathrm{~N}$ onsignificant or significant at $\mathrm{P}<0.05$ or 0.01 , respectively. 
$\mathbf{A}$

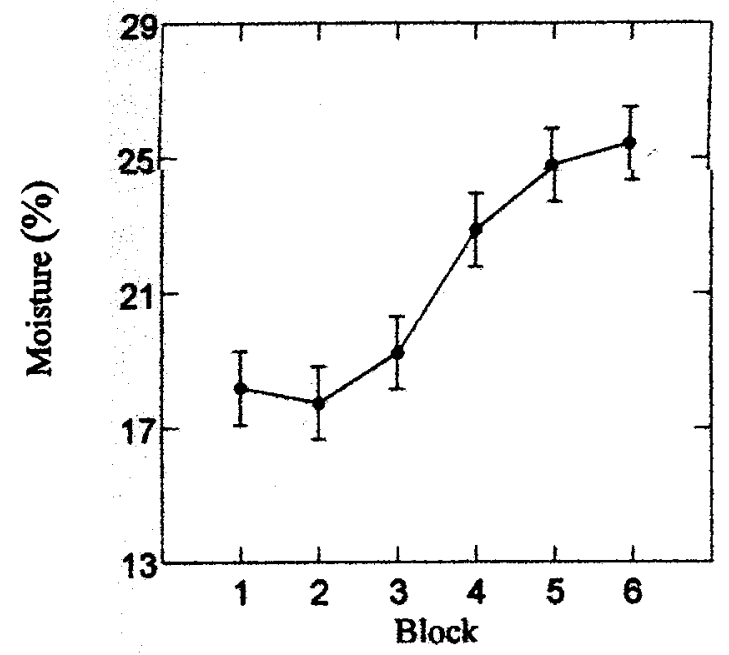

B

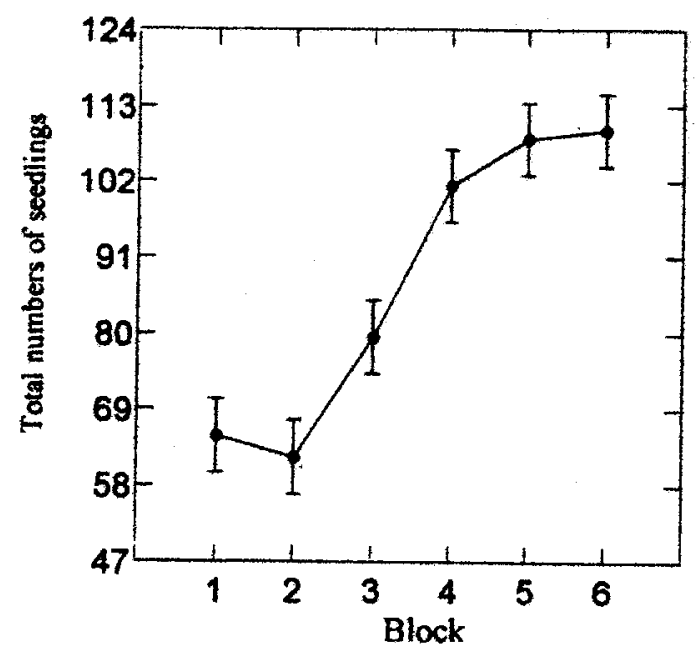

C

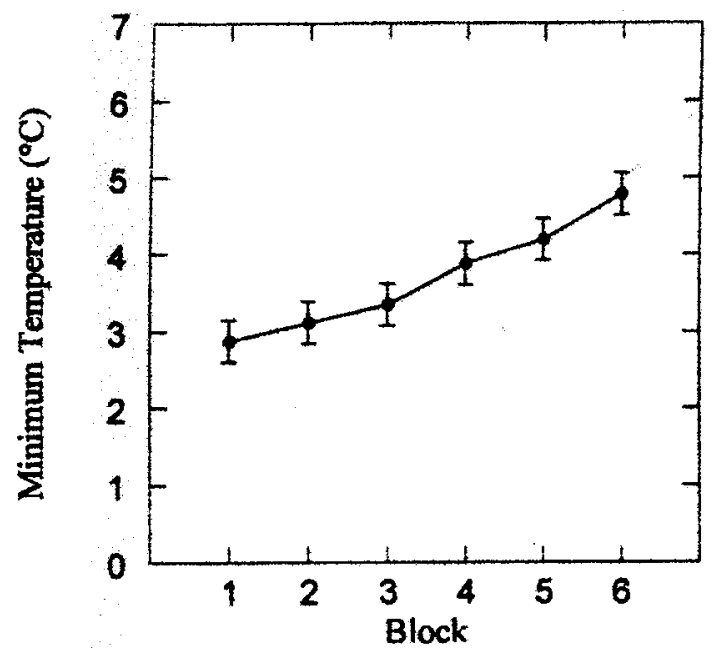

Fig. 4. (A) M ean percent soil moisture, (B) total seedling numbers emerged, and $(C)$ mean minimum daily temperature with standard error bars for each of the six blocks in Expt. 2; ${ }^{\circ} \mathrm{F}=1.8\left({ }^{\circ} \mathrm{C}\right)+32$.
The average minimum temperature in block 1 to that in block 6 ranged from 2.5 to $4.7^{\circ} \mathrm{C}\left(36.5\right.$ to $\left.40.7^{\circ} \mathrm{F}\right)$, which could have been a major influence on the establishment of the sweet corn. These minimum temperatures corresponded well not only with the total numbersindex, but also with the average weight index showing that blocks that did not reach the lower temperatures grew more plants at a higher averageweight than blocksthat reached the coldest temperatures.

It was suspected that the darker Kokomo soil would warm faster thus accumulating heat units more quickly than the Crosby and transition soils. Thiswould havesupported data showing earlier and more rapid emergence on the Kokomo soil. H owever, heat units actually accumulated faster on thelighter colored C rosby soil, counter to the hypothesis. To investigate further, maximum and minimum temperatureswere averaged for the C rosby soil. These resultswerethen plotted by date showing the daily average maximum and minimum temperatures for each of the planting depths in the Crosby soil. The same procedure was carried out for the Kokomo soil. Results show that, typically, soil temperatures were about $2^{\circ} \mathrm{C}\left(3.6^{\circ} \mathrm{F}\right)$ cooler in the evening on the $\mathrm{C}$ rosby soil but also reached maximum temperature 3 to $4.5^{\circ} \mathrm{C}$ ( 5.4 to $\left.8.1^{\circ} \mathrm{F}\right)$ warmer than the Kokomo soil (data not shown). Theseresultswere consistent throughout the study period, explaining why heat units accumulated faster on the Crosby soil series.

Kokomo soil had higher moisture levels than the Crosby when tested with the neutron probe. The extra water in the soil may have acted as a buffer against temperaturefluctuations that kept the Kokomo soil from reaching the same extremes as the C rosby. Perhaps smaller temperature fluctuation provided abetter environment for germination, or small differences in nightly minimum temperatures reached on the Crosby soil may have been enough to inhibit sh2 sweet corn germination. In either case, it may prove more beneficial to consider the length of time that soil remains at critical temperatures. With data loggers this type of analysis becomes possible, instead of relying solely on maximum and minimum temperatures.

Thereweresignificant differences in soil dry density running north to 
Table 6. Soil dry density and percent moisture for spring study at $\mathbf{1 4} \mathbf{d}$ after planting.

\begin{tabular}{lcc}
\hline Block & $\begin{array}{c}\text { Mean dry } \\
\text { density } \\
\left.\left[\mathbf{k g} \cdot \mathbf{m}^{-2}\right)\left(\mathbf{l b} / \mathbf{f t}^{2}\right)\right]\end{array}$ & $\begin{array}{c}\text { Avg } \\
\text { moisture } \\
\mathbf{( \% )}\end{array}$ \\
\hline 1 & $1.29(0.296)$ & 17.8 \\
2 & $1.29(0.296)$ & 17.6 \\
3 & $1.29(0.296)$ & 19.1 \\
4 & $1.29(0.296)$ & 19.8 \\
5 & $1.19(0.273)$ & 24.8 \\
6 & $1.24(0.284)$ & 24.0 \\
& $\mathrm{SE}=0.02$ & $\mathrm{SE}=0.72$ \\
\hline
\end{tabular}

T able 7. Soil nutrient levels for spring study sampling sites.

\begin{tabular}{lrrrr}
\hline Level & $\mathbf{P}$ & \multicolumn{1}{c}{$\mathbf{K}$} & $\mathbf{C a}$ & $\mathbf{M g}$ \\
\hline M inimum & & \multicolumn{2}{c}{$\left[\mathbf{m g}^{-\mathbf{2}} \mathbf{( \mathbf { p p m } ) ]}\right.$} & \\
M aximum & 35 & 133 & 1440 & 225 \\
M ean & 75 & 276 & 3000 & 383 \\
SD & 59 & 195 & 2200 & 297 \\
& 7 & 35 & 420 & 43 \\
\hline
\end{tabular}

south through thefield, with $P=0.006$ between blocks with blocks 5 and 6

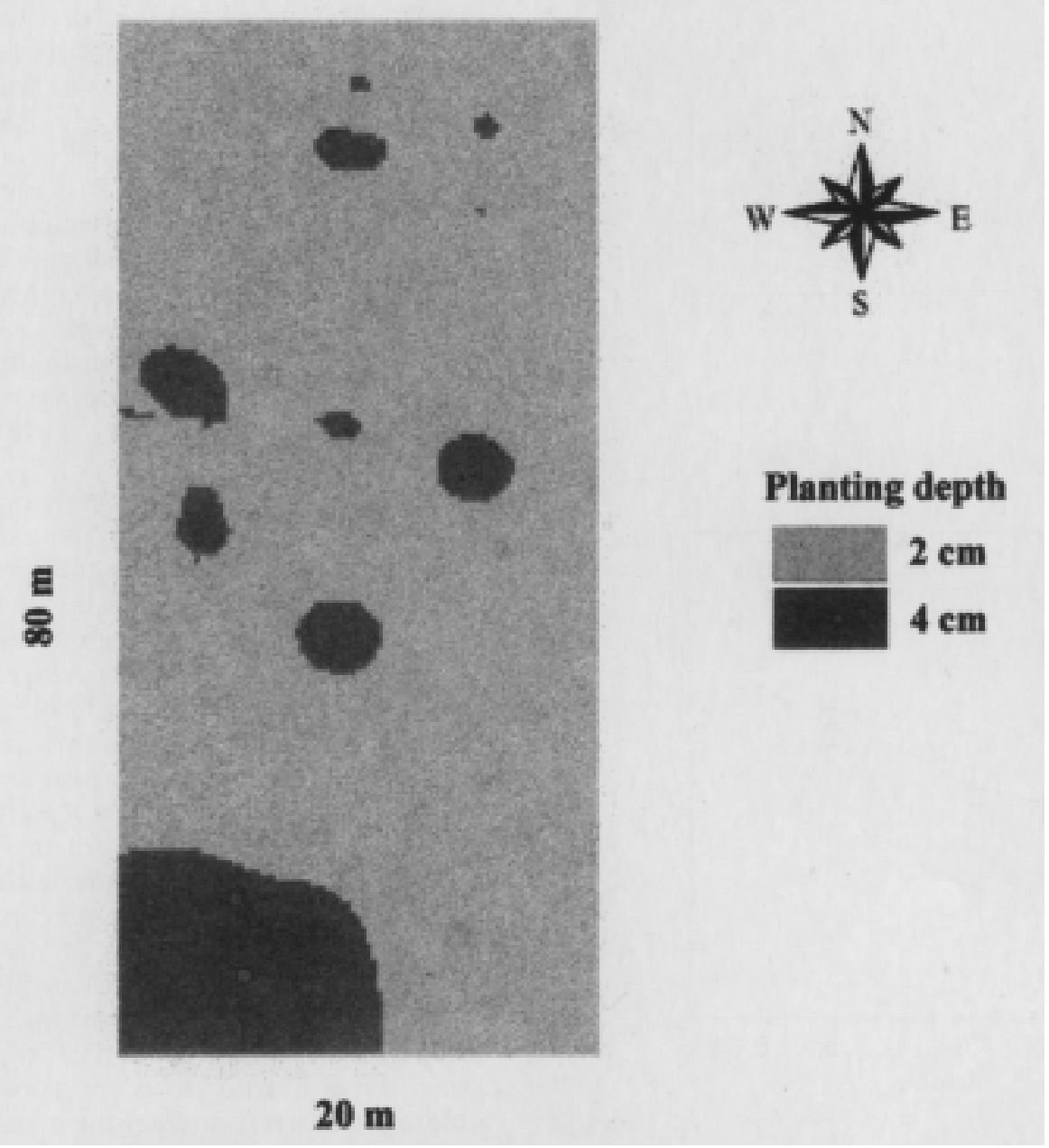

Fig. 5. Planting depth recommendations for 'Skyline' using Arcview; $\mathbf{2} \mathrm{cm}=\mathbf{0 . 8}$ inches, $4 \mathrm{~cm}=1.6$ inches, $20 \mathrm{~m}=66 \mathrm{ft}, 80 \mathrm{~m}=262 \mathrm{ft}$.
6 were contained in the Kokomo soil series showing that it was less compact than the other soil types (data not shown). Dry density testing showed an inverse relationship in soil compaction and moisture. In general, themore moisture the soil held at the time of sampling, the less compact the soil was. The fact that the emergence indices show higher germination in the darker soils may suggest that the less compact soil favored germination. The same conclusion would not be drawn from the moisture data. Although blocks 5 and 6 had the highest percent moisture and ranked high in emergence indices, there is definitely a limit to desirable percent moisture. Planting sh2 seed in overly wet conditions ( $>24 \%$ soil moisture) led to a poor stand as the total numbers index showed fewer seedlings in the stand at the $6-\mathrm{cm}$ depth for all three cultivars. The 6-cm depth also had the lowest average seedling weight for all cultivars and the greatest number of seedlings that died after emergence. In both years, moisture was directly related to depth as all soil types held more moisture the deeper they were sampled.

According to the soil test report, all positionstested had good or excessive levels of nutrients. Although there weresignificant differencesin all nutrients tested between blocks, even the lowest levels should not hinder the germination and growth of these sh2 sweet corn cultivars (Table 7).

There were no significant differences seen in soil compaction over east or west directions (data not shown) and soil nutrient levels had been more than adequate over the entire field. Soil moisture and minimum temperature were more related to final stand than any of the other tested parameters. There were only six sites where soil moisture and temperature were tested which were in the middle of each block (Fig. 1). I more points had been sampled, a trend in emergence patterns with smaller pockets of soil moisture and temperature fluctuation could be discussed.

Although the 2-cm depth would typically produce higher emergence in the final stand of 'Skyline' than the other planting depths, there were areas scattered in the northern and central field and the so uthwest corner that would have greatest stand establishment at the 4-cm planting depth (Fig. 
A

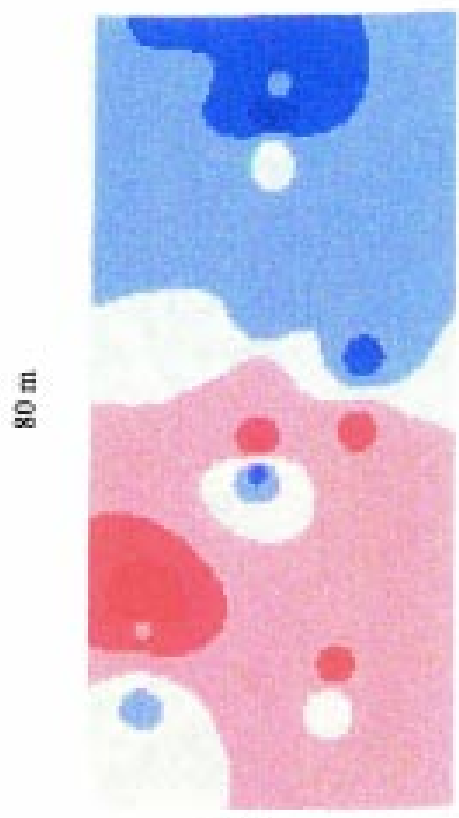

$20 \mathrm{~m}$

B

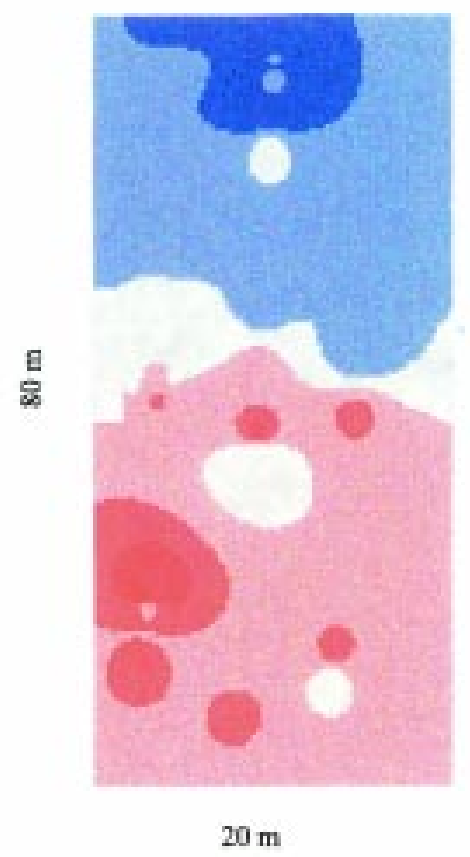

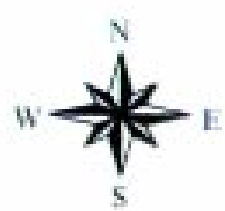

\% emergence at $2 \mathrm{~cm}$
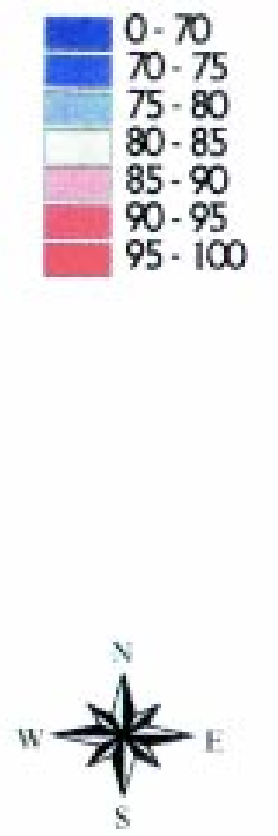

\% emergence at variable depth

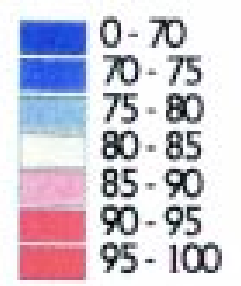

Fig. 6. Projected stand establishment if 'Skyline' planted at (A) $2 \mathrm{~cm}(0.8$ inches) over entire field and (B) 2 and $4 \mathrm{~cm}$ ( 0.8 and 1.6 inches) variable depth; $20 \mathrm{~m}=66 \mathrm{ft}, 80 \mathrm{~m}=262 \mathrm{ft}$.

5) according to ArcView analysis. Areas that were not planted between soil types show the 2-cm planting depth recommendation (Fig. 5) but these areas are not as certain since ID W was used to interpolate the surface of these maps. $\mathrm{N}$ early half of the Kokomo soil series that was actually planted in the study hasa planting depth recommen-

dation of $4 \mathrm{~cm}$ (Figs. 1 and 5). Corresponding latitudeand longitude points could be programmed into planting equipment so that planting depth could be varied between 2 and $4 \mathrm{~cm}$ over the field. 'Skyline' planted at $2 \mathrm{~cm}$ over the entire field would have resulted in some northern areas with less than $70 \%$ emergence, and areasin the south- ern end of the field with less than $80 \%$ emergence (Fig. 6A). When the variable planting depth scenario was used, there was no area in the field with less than $70 \%$ emergence and the southern half of the field had final stands of $80 \%$ emergence or higher (Fig. 6B).

Because 'Skyline' planted at the 2-cm depth emerged more quickly (in the spring study) on the Crosby soil than the other planting depths, the 2$\mathrm{cm}$ planting depth should be used exclusively on the Crosby soil series. Since blocks in the Crosby soil had significantly cooler soil temperatures than the central and southern blocks (Fig. 4C), it may be advantageous to plant blocksin the $\mathrm{Crosby}$ soil at a later planting date than the Kokomo soil series.

\section{Conclusions}

Significant variability was found within the $80 \times 20 \mathrm{~m}$ field with respect to soil moisture, temperature, nutrient levels, and compaction. Soil moisture seemed to correspond to emergence levelsbut actual differenceswere probably due to soil series changes. Low temperatureswere detrimental to good stand establishment in the C rosby soil and a recommendation was made to postpone the planting date on the Crosby soil series. It was determined that the Crosby soil series was 3 to 4.5 ${ }^{\circ} \mathrm{C}$ warmer than the Kokomo soil series during the day, but averaged $2^{\circ} \mathrm{C}$ cooler minimum temperatures than the Kokomo at night. Thus, heat units accrued faster on the Crosby soil but becauseseed ling emergencewasslower and less complete on the Crosby soil during thespring study, minimum temperatures from the early spring planting datehindered stand establishment. Although variability existed for soil nutrients, all levels though out the field were at good or excess levels so that nutrient levels did not affect emergence. Blocks in the Kokomo soil series had lower dry density than blocks in Crosby and transition soils.

Significant effects were seen for seedling emergence outside of cultivar vigor differences. Soil type and planting depth along with various interactions had significant impact on sh2 sweet corn emergence under field conditions. There was a near linear relationship, with the $2-\mathrm{cm}$ depth having less die off than the 4-cm and especiallythe 6 -cm planting depths. Cooler and wetter conditions are generally 
found at deeper plantings. These conditions may have led to disease or possibly the extra distance that the plant had to travel to reach the surface was the difference that caused it to deplete its energy source. ArcView proved to be a powerful tool for analysis of stand establishment of sweet corn. U sing the cultivar, Skyline, variable planting depth recommendations were made to improvestand establishment over uniform planting depth. The ability to map factors affecting seedling establishment may guide precision seeding to obtain plant population targets in the future.

\section{Literature cited}

Barr, A. 1998. Precision planting for sh2 sweet corn (Zea mays L.) stand establishment. M S thesis. O hio State U niv., C olumbus.

Cahn, M.D., J.W. H ummel, and B.H. B rouer. 1994. Spatial analysis of soil fertility for site-specific crop management. Soil Sci. Soc. Amer. J. 58:1240-1248.

Carter, L.M. and J.H. Chesson. 1996. T wo USDA researchers develop a moisture-seeking attachment for crop seeders that is designed to help growers plant seed in soil sufficiently moist for germination. Seed World ( $M$ arch):14-15.

Christensen and Krause. 1995. Precision farming: $H$ arnessing technology. Agr. O utlook. (M ay):18-19.

Colvin, T.S., D.L. Karlen, J.R. Ambuel, and $F$. Perez-M unoz. 1995. Yield monitoring for mapping, p. 5-14. In: P.C. Robert, R.H . Rust, and W.E. L arson (eds.). Site-specific management for agricultural systems. ASA-C SA-SSSA, M adison, $\mathrm{W}$ is.

G riffith, D . 1995. Incorporating economic analysis into on-farm GIS, p. 723-729. In: P.C. Robert, R.H. Rust, and W.E. Larson (eds.). Site-specific management for agricultural systems. ASA-C SA-SSSA, M adison, Wis.
H akansson, I., W.B. Voorhees, and H. Riley. 1988. Vehicle and wheel factors influencing soil compaction and crop response in different traffic regimes. Soil Till. Res. 11:239-282.

H uggins, D.R. and R.D. Alderfer. 1995. Yield variability within a long-term corn management study: I mplicationsfor precision farming, p. 417-426. In: P.C. Robert, R.H. Rust, and W.E. Larson (eds.). Sitespecific management for agricultural systems. ASA-CSA-SSSA, M adison, Wis.

Price, R.R. and L.D. Gaultney. 1993. Soil moisture sensor for predicting seed planting depth. Trans. Amer. Soc. Agr. Eng. 36(6):1703-1711.

Stafford, J.V. and B. Ambler. 1994. Infield location using GPS for spatially variable field operations. ComputersE lectronics Agr. 11:23-26.

Vansichen, R. and J. De Baerdemaeker. 1993. A measurement technique for yield mapping of corn silage. J. Agr. Eng. Res. 55:1-10.

Wallace, A. 1994. H igh-precision agriculture is an excellent tool for conservation of natural reso urces. $C$ ommun. Soil Sci. Plant Anal. 25(1\& 2):45-49.

Willis, W.O., W.E. Larson, and D. Kirkham. 1957. Corn growth as affected by soil temperatureand mulch. Agron. J. 49:323328

Wilson, D.O.Jr., J.C. Alleyne, B. Shafii, and S.K. M ohan. 1992. Combining vigor test results for prediction of final stand of shrunken-2 sweet corn seed. Crop Sci. 32:1496-1502.

Wolfe, D.W., D.T. Topoleski, N.A. Gundersheim, and B.A. Ingall. 1995. Growth and yield sensitivity of four vegetable crops to soil compaction. J. Amer. Soc. H ort. Sci. 120:956-963.

Wollenhaupt, N.C., R.P. Wolkowski, and M.K. Clayton. 1994. Nutrient management mapping soil test phosphorus and potassium for variable-rate fertilizer application. J. Prod. Agr. 7(4):441-447. 